\title{
THE GEOLOGY, AGE, NEAR SURFACE FEATURES, AND MINERALOGY OF THE MERLIN KIMBERLITES, NORTHERN TERRITORY, AUSTRALIA
}

\author{
Adrian Hell ${ }^{1}$, Prof. Ross Ramsay ${ }^{1}$, Gerard Rheinberger ${ }^{2}$ and Simon Pooley ${ }^{3}$ \\ ${ }^{1}$ Deakin University, Australia; ${ }^{2}$ Rio Tinto (Exploration), Australia $:{ }^{3}$ Merlin Diamonds Pty Ltd, Australia.
}

The Merlin kimberlite field is located in the Batten region of the southern McArthur Basin, Northern Territory, Australia (Lee et. al., 1998). The field comprises twelve single to bifurcating kimberlite pipes and two exposed sandstone breccia pipes, which occur in five clusters over an area of $10 \mathrm{~km} \times 5 \mathrm{kms}$.

A majority of the kimberlites appear along the projected trace of the regional Calvert Fault and controlled locally by 15-degree structural trends. A 340-degree structure locally termed the Merlin Fault extends from the Sacramore-Palomides pipe to the Ector and Kay cluster. Associated with these kimberlites along the Merlin and Calvert Faults are varying developments of brecciation and stock work veining likely related to precursor and post kimberlite activity.

The Merlin kimberlites intrude basement volcanics and Neoproterozoic shelf sediments, the youngest being the Bukalara Sandstone. Often associated with these pipes are an outer contact breccia, sandstone breccia, and blind kimberlite appendages.

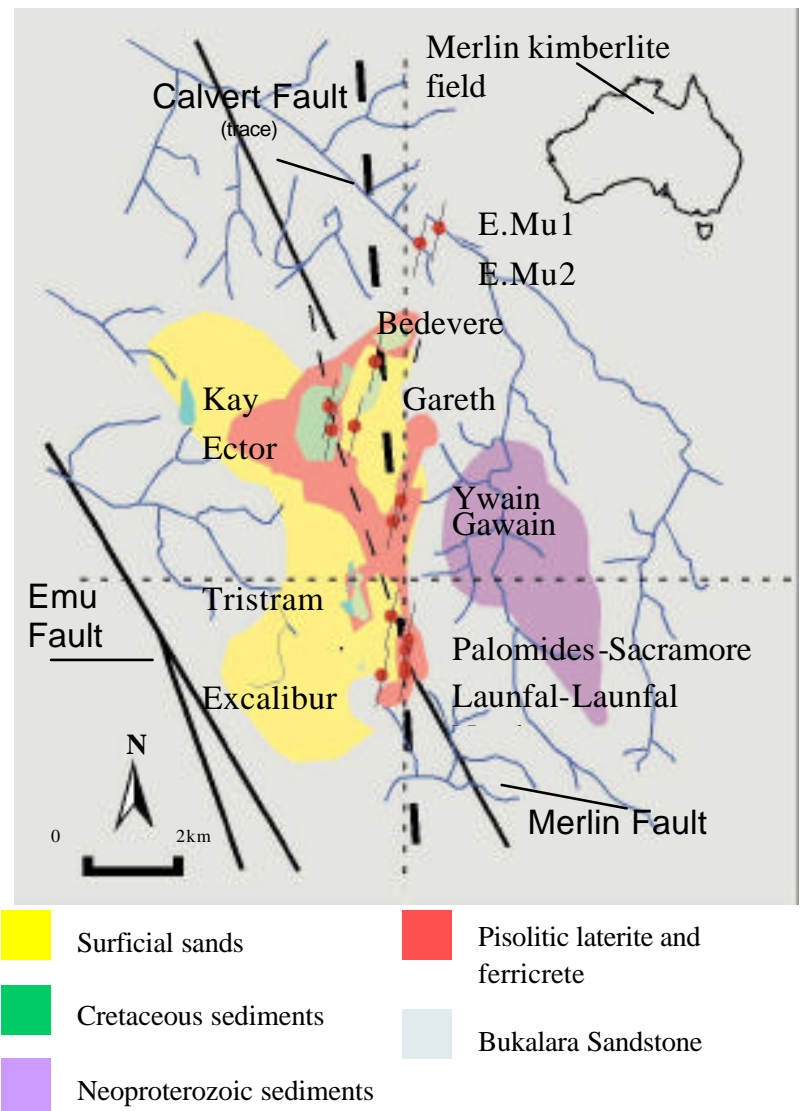

Figure 1: The Merlin kimberlite field highlighting local geology and major structural controls.

\section{AGE OF EMPLACEMENT}

${ }^{40} \mathrm{Ar} /{ }^{39} \mathrm{Ar}$ age dating on phlogopite from a number of pipes occurring to the north and south of the field give consistent emplacement ages of Middle Devonian (380 $\pm 2 \mathrm{Ma})$. These dates are consistent with previous $\mathrm{K}-\mathrm{Ar}$ (Atkinson et. al., 1990) and Rb-Sr (Reddicliffe, 1999) dating undertaken on phlogopite from the E.Mu.1 and Excalibur pipes respectively (table 1).

\section{Table 1: Radiometric Dates}

\begin{tabular}{l|c|l|l}
$\begin{array}{l}\text { Kimberlite } \\
\text { Pipe }\end{array}$ & $\begin{array}{l}\text { Textural } \\
\text { Phase }\end{array}$ & $\begin{array}{l}\text { Dating } \\
\text { Technique }\end{array}$ & $\begin{array}{l}\text { Model } \\
\text { Age (Ma) }\end{array}$ \\
\hline${ }^{1}$ E.Mu.1 & - & $\mathrm{K}-\mathrm{Ar}$ & $360 \pm 4$ \\
${ }^{2}$ Excalibur & - & $\mathrm{Rb}-\mathrm{Sr}$ & $367 \pm 4$ \\
${ }^{2}$ Excalibur & - & $\mathrm{Rb}-\mathrm{Sr}$ & $352 \pm 4$ \\
Excalibur & VK4 & ${ }^{40} \mathrm{Ar} /{ }^{39} \mathrm{Ar}$ & $377 \pm 2$ \\
$\begin{array}{l}\text { Palomides- } \\
\text { Sacramore }\end{array}$ & PLVKB1 & ${ }^{40} \mathrm{Ar} r^{39} \mathrm{Ar}$ & $382 \pm 3$ \\
Launfal- \\
$\begin{array}{l}\text { Launfal } \\
\text { North }\end{array}$ & MbVK1 & ${ }^{40} \mathrm{Ar} r^{39} \mathrm{Ar}$ & $382 \pm 2$ \\
Ector & & & \\
& PLVKB1 & ${ }^{40} \mathrm{Ar} /{ }^{39} \mathrm{Ar}$ & $380 \pm 2$
\end{tabular}

( ${ }^{1}$ after Atkinson et. al., 1990; ${ }^{2}$ after Reddicliffe, 1999)

\section{Textural PHASES}

Each kimberlite contains numerous textural phases, indicating separate \& distinctive intrusive events. Fourteen textural phases have been recognised from the Merlin pipes with up to seven separate phases forming any one body. However, drill data recorded from surface to depths of $200 \mathrm{~m}$ of kimberlites in the southern cluster, indicate usually four textural phases dominate in the near surface diatreme.

From all the textural phases identified throughout the field three major textural phase groups have been recognised. These comprise a volcaniclastic kimberlite breccia (VKB), micro-breccia volcaniclastic kimberlite $(\mathrm{mbVK})$, and a volcaniclastic kimberlite (VK) of mostly the diatreme facies (Mitchell, 1995).

In relation to one another, these three major groups exhibit sharp contacts often defined by a thin selvage of carbonate. From a number of kimberlites, especially those of the southern cluster a chronology has been developed to identify the sequence of intrusive events represented by each textural phase. These age relationships have essentially been developed by identifying autoliths within kimberlite and where possible associating them with their parental material. 
In addition, spatial relationships of each textural phase has revealed that older phases (VK- and mbVK-types) usually form central to the diatreme with younger (VKB-types) textures forming the outer peripheral zone and determining most of the overall pipe area. This work unfortunately cannot recognise the actual time difference between phases but has put forth a chronological relationship.

\section{Table 2: Textural Phases \& Volume Percentages}

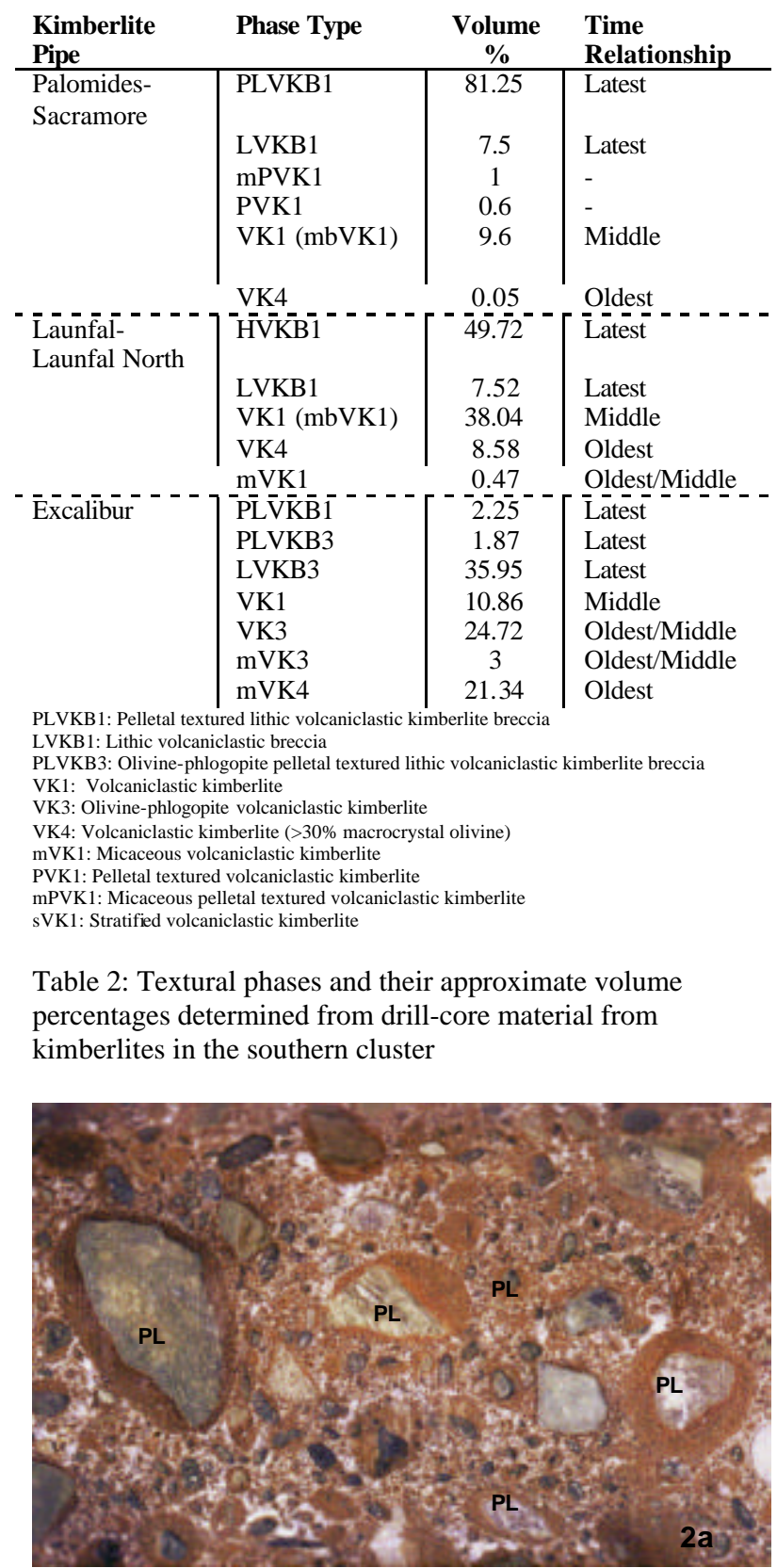

2a. Photograph of PLVKB1 phase comprising pelletal lapilli (PL) (>15 vol.\%) with xenolith cores set in a uniform finegrained carbonate groundmass.

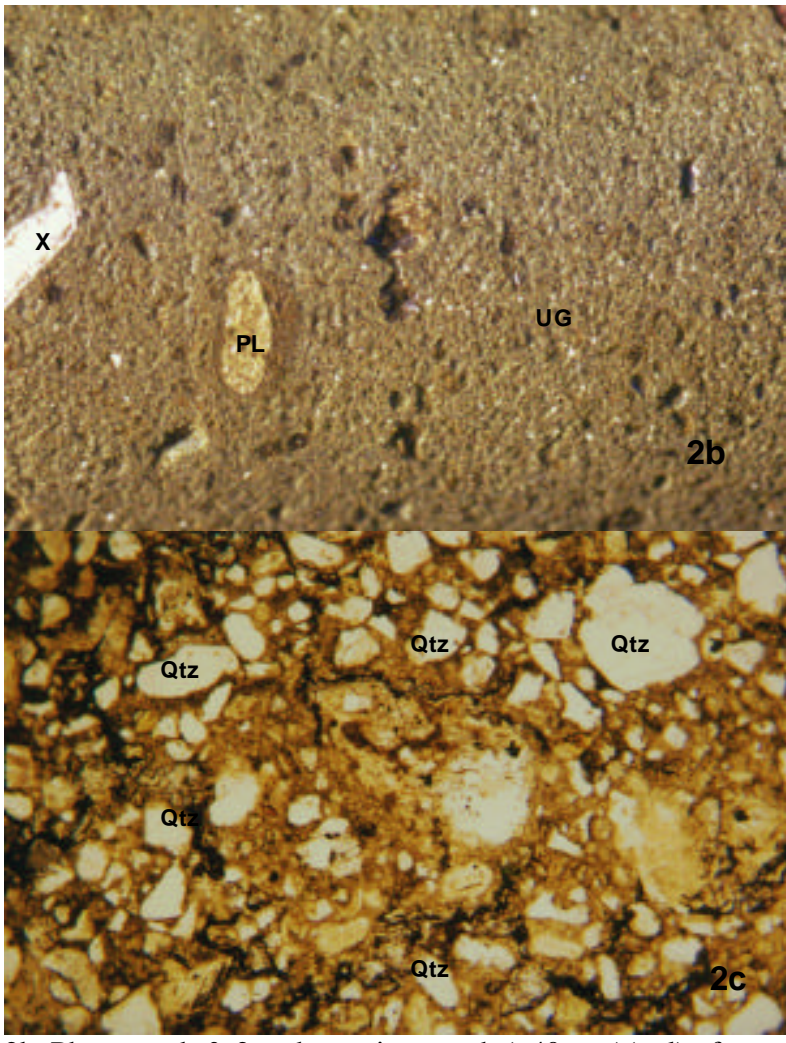

2b. Photograph \& 2c. photomicrograph (x40mag)(ppl) of mbVK1 phase with characteristic high percentage of quartz xenocrysts $(>30$ vol.\%)(Qtz). This textural phase contains low percentages of xenoliths (crustal) $(<10 \mathrm{vol} . \%)(\mathrm{X})$ and uncommon pelletal lapilli $(\mathrm{PL})(<5 \mathrm{vol} . \%)$.

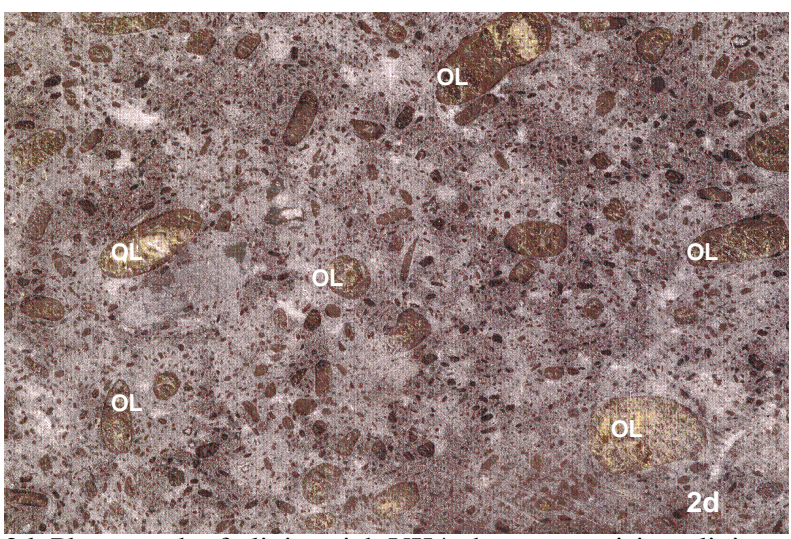

2d. Photograph of olivine-rich VK4 phase comprising olivine pseudomorphs $(\mathrm{OL})(>30 \mathrm{vol}$. \%) now altered to serpentine, set within a fine grained uniform serpentine $\&$ carbonate groundmass.

Figure 2a, 2b, 2c\&2d: Photo and photomicrographs of major textual phase groups of the Merlin kimberlites.

A clear relationship has been observed between these three major textural phase groups and their degree of interaction $\&$ association with surrounding near surface crustal material. The magmatic phases, including VKtypes, occur as the initial and most passive style intrusion containing low percentages of crustal wall rock (<10 vol. \%). These phases appear as multiple or single intrusions within the overall pipe and may develop as proximally associated terminating dykes. The following intrusive development, defined by the 
mbVK-type phase removes a high proportion of xenocrysts (> 30 vol. \%) from he surrounding wall rock, however does not commonly incorporate xenolithic material $(<10$ vol. \%). The final intrusive activity, which largely controls the final design of the upper diatreme body, are the VKB-type phases. These textural phases having a high percentage of xenoliths and xenocrysts $(>10<95$ vol. \%) represent the final and most eruptive event forming the diatreme. These textural phases have removed and encapsulated high percentages of country rock material, including large sections of rafted wall rock. Additionally, pelletal lapilli and autoliths are common within these phases indicating the explosive, volatile and destructive nature of the system.

Both the mbVK-type and VKB-type phases occur as either single or bifurcating bodies which hemselves appear to be associated with major lithological boundaries. These later or younger phases contribute to the greater proportion of the overall design of the near surface diatreme.

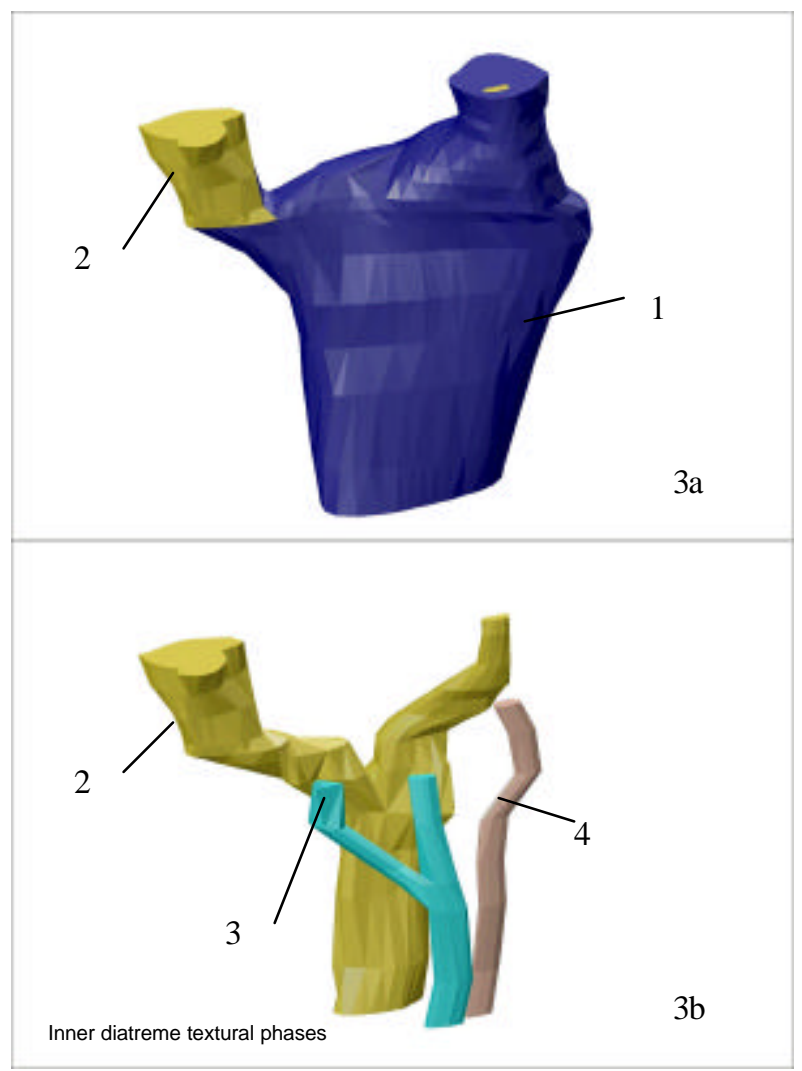

3a. \& 3b. Palomides-Sacramore kimberlite: bifurcating pipe, with major textural phases incl. 1. PLVKB1, 2. mbVK1, 3. LVKB1 \& 4. mVK1.

Figures 3a,b,\&c: Characteristic pipe morphologies of the Merlin kimberlites with textural phase spatial relationships from the bifurcating Palomides-Sacramore and single Excalibur pipes.

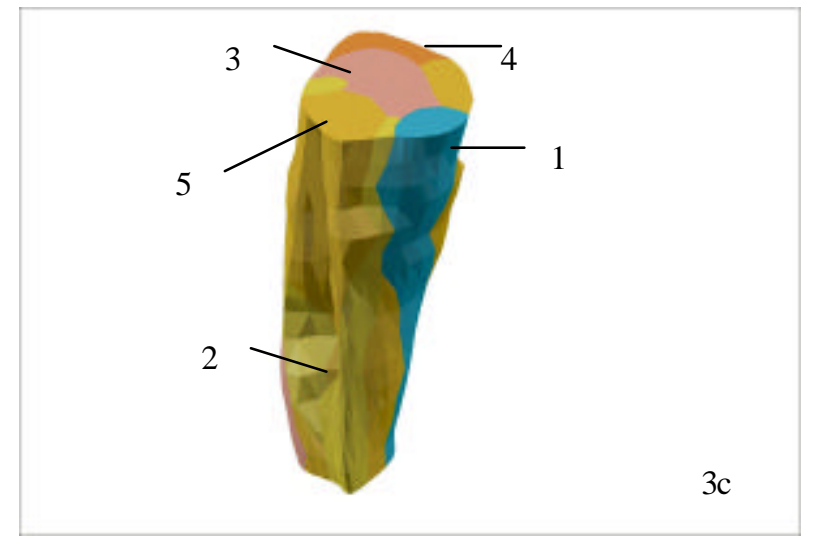

3c. Excalibur kimberlite: single pipe body with major textural phases incl. 1. LVKB3, 2. mbVK1, 3. VK3, 4. mVK3, \& 5. mVK4

\section{INFILL SEQUENCES}

A localised and restricted Cretaceous marine infillsequence and a thickened Tertiary weathering profile overly all kimberlites in the field except for the E.Mu pipes. These infill sediments comprise conglomerate, bioturbated sandstone and claystone units, which commonly 'cork' the kimberlite, circumscribed by the Bukalara Sandstone wall rock. Rarely do these sediments persist outside the pipe area, which themselves appear to be associated with erosional lows throughout the Bukalara Sandstone (Hell et. al., 2002).

The basal part of the infill sequences is defined by a pebble-cobble conglomerate often containing belemnite fossils [Peratobelus bauhinianus (Skwarko, 1966)]. These sediments are virtually absent of diamonds and indicator minerals (Kammermann, 1999), but commonly contain clast types, likely to be resistive xenolithic material derived from the kimberlite. These include chert, sandstone and mudstone often cemented by a ferruginised sand and clay matrix. The conglomerate has an average thickness of $0.4 \mathrm{~m}$ across the surface area of the kimberlite, and at the periphery of the pipe the unit persist vertically up following the truncated contact with the Bukalara Sandstone wall rock.

Conformably overlying the conglomerate is a thickly bedded bioturbated sublitharenite sandstone. A number of fossil assemblages have been recognised throughout these sediments including Aptian-Ablian aged ammonites (Archbold, 1997), gastropods, bivalves, rare bryozoa and many indeterminate fossil fragments. The infill-sandstone has a relatively consistent thickness over all kimberlites, where it ranges from $8.0-12.0 \mathrm{~m}$.

A medium-coarse sublitharenite sandstone is restricted to Gareth pipe. This unit, with an average thickness of $3.0 \mathrm{~m}$, overlies the conglomerate and is overlain by the bioturbated sandstone.

A featureless kaolinitic claystone overlies the bitotubated sandstone and is only present over some kimberlite pipes. The claystone ranges in thickness from $2.0-18.0 \mathrm{~m}$ and is notably thicker over smaller diameter pipes. 
These sediments contain arenaceous foraminifera fossil assemblages of Albian-Cenomanian age (Krassay, 1999). A thin clayey sandstone defines the gradational contact between the bioturbated sandstone and claystone sequence.

Slickensided features observed near the margins of the kimberlite, slumping features, and an increase in jointing within the infill-sediments suggest these kimberlites have undergone contemporaneous and/or post depositional subsidence, which subsequently preserved a locally unique Cretaceous sequence. Smaller diameter pipes display a greater depth of retreat, which may reach depths of $42 \mathrm{~m}$. It is suggested the subsidence be related to solution weathering (Reddicliffe, 1999), hydrothermal alteration, or possibly halmyrolysis. Localised faulting may have also played a contributing factor to the preservation of these sediments.

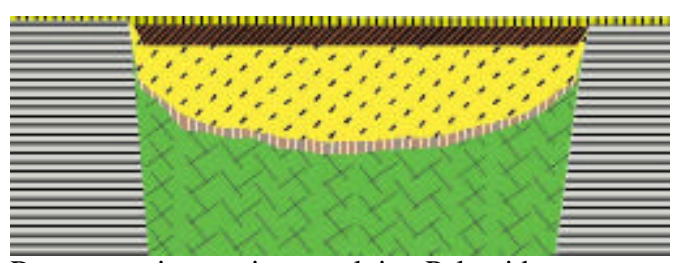

Representative section overlying Palomides-

Sacramore, Launfal section, and Kay kimberlites.

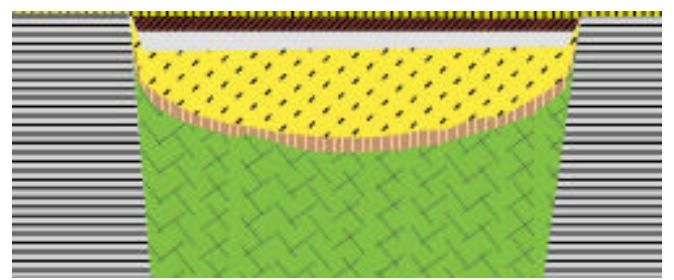

Representative section overlying Launfal North section, Excalibur, Tristram, Gawain, Ywain and Bedevere kimberlites.

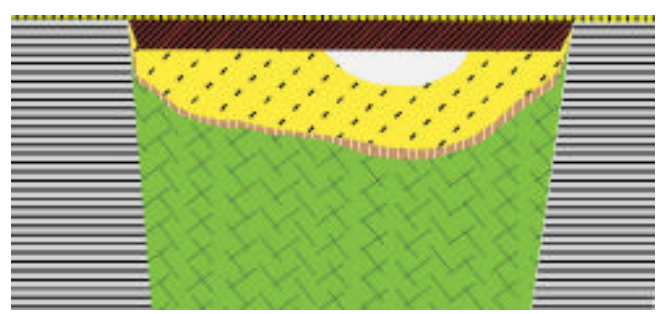

Representative section overlying Ector kimberlite.

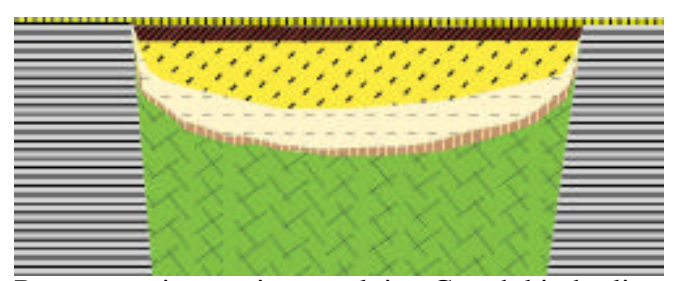

$\overline{\overline{\text { Representative section overlying Gareth kimberlite. }}}$

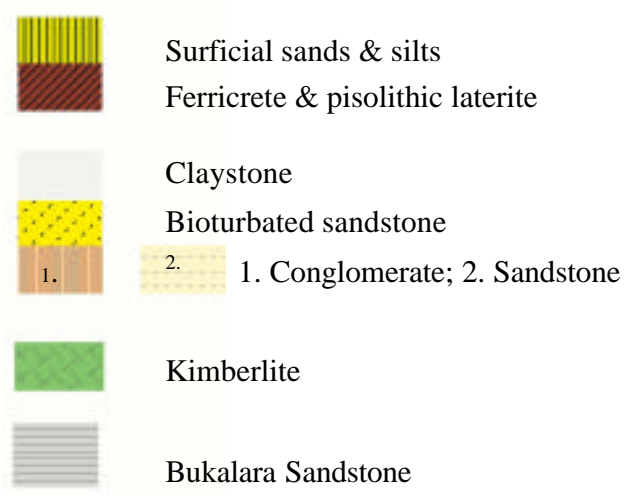

Figure 4: Infill sequences over the Merlin kimberlites

\section{MINERALOGY}

Primary kimberlite mineralogy is often extensively altered and comprises two generations of pseudomorphed olivine (5-45 vol.\%) now altered to serpentine, carbonate, clay and silica. The kimberlite composition mostly comprises an inequigranular assemblage with rounded to subhedral macrocryst and euhedral to subhedral phenocryst and groundmass olivines. Olivine macrocrysts replaced by serpentine commonly have an associated outer microcrystalline serpentinised rim. Other primary phases include tabular and poikilitic phlogopite (5-35 vol. $\%)\left(\mathrm{Al}_{2} \mathrm{O}_{3}\right.$ 0.21-17.24 wt. $\%, \mathrm{Cr}_{2} \mathrm{O}_{3}$ 0.00-1.79 wt. $\%, \mathrm{FeO} 4.2-15.55$ wt.\% , and $\mathrm{TiO}_{2}$ 0.11-4.99 wt.\%: after Reddicliffe, 1999) encasing chromite, macrocrystal chromite $(\mathrm{Cr} / \mathrm{Cr}+\mathrm{Al}$ 0.2-0.95, $\mathrm{MgO} 8-17$ wt.\% , $\mathrm{TiO}_{2}$ 0-4.3 wt\% after Reddicliffe, 1999), pyrope garnet (<5 vol.\%) $\left(\mathrm{Cr}_{2} \mathrm{O}_{3} 2-12\right.$ wt.\%, \& $\mathrm{CaO}$ 1-7 wt.\%: after Reddicliffe, 1999), apatite, and possibly rare picro-ilmenite. Secondary alteration phases and groundmass mineralogy often comprise calcite, serpentine, chromite ( $<5$ vol. $\%)$, chlorite, and kaolinite. Accessory phases comprise zircon, rutile and rare tourmaline.

The whole rock geochemistry for the Merlin kimberlites conform to definitions for average Group I kimberlites (Mitchell, 1995) (average incompatible trace elements: Sr 638, Y 110, Zr 167, Nb 234, Cs 5, Ba 4588, Th 76, U 12, \& Hf 2.38) (Major elements: $\mathrm{SiO}_{2}$ 21-39 wt.\%, $\mathrm{Al}_{2} \mathrm{O}_{3} \quad 2-6$ wt. $\%, \quad \mathrm{Na}_{2} \mathrm{O}+\mathrm{K}_{2} \mathrm{O} / \mathrm{Al}_{2} \mathrm{O}_{3} \quad 0.03-0.3, \quad$ \& $\left.\mathrm{Na}_{2} \mathrm{O}+\mathrm{K}_{2} \mathrm{O} / \mathrm{Al}_{2} \mathrm{O}_{3} 0.25-0.69\right)$.

The mineral chemistry of pyrope garnet $\left(\mathrm{Cr}_{2} \mathrm{O}_{3} 2-12 \%\right.$, \& $\mathrm{CaO} 1-7 \%)$ and macrocrystal chromite $(\mathrm{Cr} / \mathrm{Cr}+\mathrm{Al}$ $20-95 \%, \mathrm{MgO} 8-17 \mathrm{wt} \%, \mathrm{TiO}_{2}$ 0-4.3 wt $\%$ ) indicate all pipes have the potential to host diamonds. Additionally, the mineral chemistry of groundmass chromites displays a population consistent with sampling within the diamond inclusion field and a second population falling outside. These contrasting populations may indicate a high $(\mathrm{Cr} / \mathrm{Cr}+\mathrm{Al}$ 0.80-0.90, $\left.\mathrm{Al}_{2} \mathrm{O}_{3} 4-5 \mathrm{wt} \%\right)$ and low $\left(\mathrm{Cr} / \mathrm{Cr}+\mathrm{Al} 33-73 \%\right.$, \& $\mathrm{Al}_{2} \mathrm{O}_{3} 3-$ $35 \%$ ) diamond potential between pipes and individual textural phases throughout the field. 

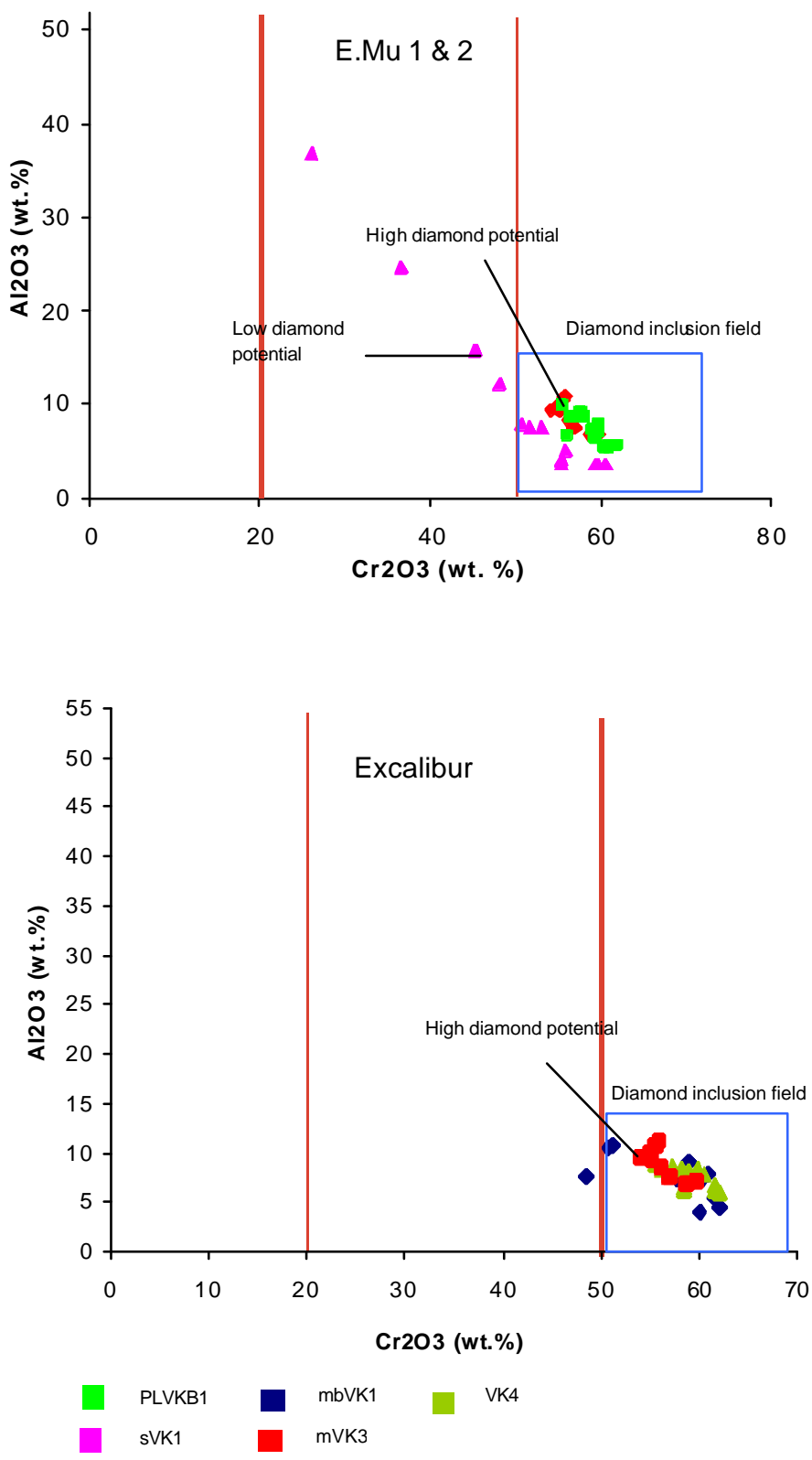

Figure 6: Composition plots for E.Mu 1\& 2 \& Excalibur kimberlites. Two examples of groundmass spinel (chromite) composition plots using diagrams constructed by Ramsay (1992) define two populations, which fall within and outside the diamond inclusion field. These results may relate to a high or low diamond potential for the kimberlite pipes and in some instances individual textural phases throughout current Merlin field.

\section{References}

Archbold, N.W., 1997. Report on the palaeontological and sedimentological materials from the Merlin exploration area, Northern Territory: Melbourne, Deakin University, pgs 12.

Atkinson, W.J., Smith, C.B., Danchin, R.V., Janse, A.J.A., 1990. Diamond deposits of Australia, In Geology of the mineral deposits of Australia and Papua New Guinea (Ed. F.E. Hughes). (The Australasian Institute of Mining and Metallurgy: Melbourne) pp 69-76.

Hell, A.J., Ramsay W.R.H., Rheinberger, G., Reddicliffe, T.H., Tyler E.W.J., Archbold, N.W., 2002: The stratigraphy and geological significance of the infillsequences in the Merlin kimberlite field, Northern Territory, Australia (abstract). Global exploration 2002: integrated methods for discovery, Society for Geology Applied to Mineral Deposits, and Society of Economic Geologists.

Kammermann, M., 1999. Sampling of the conglomerate unit from the Merlin pipes, Ashton Mining Ltd, Report No. 99008, pgs 2.

Krassay, A.A., 1994. The Cretaceous stratigraphy and palaeogeography of the western and southwestern margins of the Gulf of Carpentaria, Northern Territory [Ph.D. thesis]: Adelaide, University of Adelaide.

Lee, D.C., Reddicliffe, T.H., Scott Smith, B.H., Taylor, W.R., Ward, L.M., 1998. Merlin diamondiferous kimberlite pipes, In Berkman, D.A., Mackenzie, D.H, ed., Geology of Australian and Papua New Guinean Mineral Deposits (the Australian Institute of Mining and Metallurgy): Melbourne, pp.461-464.

Mitchell, R.H., 1995. Kimberlites, orangeites, and related rocks: Ontario, Plenum Press, pgs 410.

Ramsay, R.R., 1992. Geochemistry of diamond indicator minerals [Ph.D. thesis] University of Western Australia.

Reddicliffe, T.H., 1999. Merlin kimberlite field, Batten Province, Northern Territory [Masters thesis]: Perth, University of Western Australia. pgs 221.

Skwarko, S.K., 1966. Cretaceous stratigraphy and palaeontology of the Northern Territory: Bureau of Mineral Resources, Geology and Geophysics, Bulletin No. 73, pgs 133 .
Contact: AJ Hell, Deakin University (Melbourne Campus), 221 Burwood Hwy, Burwood, Australia, 3125, E-mail: hell@deakin.edu.au 